\title{
Impact of the use of multiplex PCR on etiological diagnosis and treatment of acute respiratory infections in a private hospital of the north of the country
}

\author{
Diana G. Hernández-González, ${ }^{1}$ Lorena Rodríguez-Muñoz ${ }^{2 *}$ and Fortino Solórzano-Santos ${ }^{3}$ \\ ${ }^{1}$ Pregraduate Department, Hospital Christus Muguerza, Saltillo, Coahuila; ${ }^{2}$ Pediatric Infectology Department, Hospital Christus Muguerza, Saltillo, \\ Coahuila; 'Infectious Diseases Research Unit, Hospital Infantil de México "Federico Gómez", Instituto Nacional de Salud, Mexico City. Mexico
}

\begin{abstract}
Background and objective: Diseases of the respiratory system represent one of the leading causes of medical care and antibiotic prescriptions. Currently, new technologies are used for the diagnosis of respiratory diseases of viral origin, such as the FilmArray Respiratory Pane ${ }^{\circledR}$, approved in 2012 by the FDA. The purpose of this study was to identify the correlation between the diagnosis and treatment of respiratory tract infections and the result of the polymerase chain reaction test for respiratory viruses. Material and methods: The study is of a retrospective, cross-sectional, descriptive type. One-hundred and thirty-four patients who underwent a viral panel for respiratory viruses, which was positive for one or more viruses, were included. For all cases, the positive results of said test and the treatment received by patients were analyzed. Results: Of the patients who underwent nasopharyngeal aspirate during hospitalization, $58 \%$ received antibiotic treatment at admission, $13 \%$ received combined treatment (antibiotic + antiviral), $27 \%$ of the patients received symptomatic treatment since admission and $2 \%$ did it with antivirals. After receiving a positive result for respiratory viruses, $38 \%$ continued with antibiotics, $30 \%$ with antibiotics and antivirals, $13.8 \%$ were managed only with antivirals and $18.2 \%$ with symptomatic treatment. Conclusion: Despite the global alert regarding antimicrobial resistance, patients continue to be treated with antibiotics, due to a situation that we ignore, but that is believed to be influenced by several factors.
\end{abstract}

KEY WORDS: Respiratory infections. PR FilmArray. Antibiotics.

\section{Impacto del uso de PCR múltiple en diagnóstico etiológico y tratamiento de infecciones respiratorias agudas en un hospital privado del norte del país}

\section{Resumen}

Antecedentes y objetivo: Las enfermedades del sistema respiratorio son causa frecuente de prescripción de antibióticos. Actualmente se emplean nuevas tecnologías para su diagnóstico como el FilmArray Respiratory Panel. El objetivo de este estudio es identificar la correlación entre el diagnóstico y tratamiento de infecciones de vías respiratorias con el resultado de PCR para virus respiratorios. Material y métodos: Estudio descriptivo, transversal, retrospectivo, se incluyeron 134 pacientes atendidos en el Hospital Christus Muguerza en Saltillo, Coahuila. Para todos los casos se analizaron los resultados del panel y el tratamiento que recibieron los pacientes. Resultados: El $58 \%$ recibió tratamiento antibiótico a su ingreso, el $13 \%$ tratamiento combinado (antibiótico + antiviral), $27 \%$ recibió tratamiento sintomático y el $2 \%$ fue tratado con antiviral de primera instancia. Posterior al resultado el 38 \% continuó con antibiótico, el 30 \% con antibiótico y antiviral, 13.8 \% se manejó con 
antiviral y el $18.2 \%$ con tratamiento sintomático. Conclusión: A pesar de la alerta mundial por la resistencia a los antimicrobianos se sigue tratando a los pacientes con antibióticos, por una situación que se cree está influenciada por varios factores.

PALABRAS CLAVE: Infecciones respiratorias. PR FilmArray. Antibióticos.

\section{Introduction}

Respiratory tract diseases are one of the leading causes of medical care in the world. These are common ailments at all ages, and their etiology varies depending on age, environmental circumstances, climate, healthcare setting and underlying conditions. ${ }^{1,2}$ Most respiratory infections only affect the upper respiratory tract and can be considered mild, benign and self-limiting (common cold, rhinitis and pharyngotonsillitis). In Mexico, acute upper respiratory infection is considered the leading cause of disease and the primary reason for seeking medical attention. Respiratory viruses are the main cause in up to $70-90 \%$ of cases. Rhinovirus has been documented in adulthood, followed by $A$ and $B$ influenza virus, coronavirus, and adenovirus; the most common in children are respiratory syncytial virus (RSV), 1,2,3 parainfluenza virus, influenza $A$ and $B$ virus, adenovirus and rhinovirus. At a smaller proportion, between 15 and $30 \%$ of cases in children and between 5 and $20 \%$ in adults, etiology is bacterial: Streptococcus pyogenes, Streptococcus pneumoniae, Mycoplasma pneumoniae, Neisseria meningitidis and Neisseria gonorrhoeae. ${ }^{3}$

Among respiratory diseases, it has been estimated that only $5 \%$ may involve the lower and middle respiratory tract (bronchitis, bronchiolitis, and pneumonia); these cases are potentially more serious and many of them require hospital admission. ${ }^{4}$ Complications of these diseases in adulthood are related to patient comorbidities and senescence. . $^{2,5}$, Lower respiratory tract acute infections, together with other chronic lung diseases, are considered to be among the most common causes of severe illness and death worldwide. ${ }^{7}$

In previous years, identifying viral etiology was methodologically difficult, which is why in few hospitals was it investigated. In recent years, the techniques for respiratory tract infections diagnosis have advanced, with detection of viral nucleic acids currently being used, with tests such as polymerase chain reaction (PCR), which has a sensitivity of 95 to $100 \%$ and specificity of 99 to $100 \% .{ }^{8}$ Given that it is common for more than one virus to be involved in these infections, it was necessary to design multiplex PCR methods, by means of which different viruses can be simultaneously identified. ${ }^{9}$ Other options include PCR coupled to optical enzyme immunoassays, which are systems for detecting amplification products using probes that are immobilized on a surface of different chemical nature. ${ }^{2}$

Current situation regarding the use of antibiotics, antivirals and other antimicrobials is increasingly alarming; although antimicrobial resistance is known to be a phenomenon that appears naturally over time, this process is accelerated by inappropriate use of antimicrobials, as well as excessive prescription thereof. The use of antibiotics is considered unnecessary or inappropriate in up to half the patients. ${ }^{10-12}$

It is hoped that when doctors can have access to studies that allow them to identify the possible etiology of the respiratory infection they are treating, they will make a more rational use of antibiotics. In this study, therapeutic behavior was evaluated when doctors were given a positive result identifying respiratory viruses in a private hospital. The most common viral agents and respiratory pathologies that were found in subjects who underwent the test are described.

\section{Material and methods}

A retrospective, cross-sectional, descriptive study was carried out. Patients of all ages who had had positive results for respiratory viruses on a multiplex PCR test performed within the period from January 2017 to March 2019 were selected. Patients with a complete medical record in a private hospital of the city of Saltillo, Coahuila, were included.

All patients included in the study underwent a PCR test for respiratory viruses during their hospital stay. The FilmArray Respiratory Panel ${ }^{\circledR}$ (RP) was used, which is a qualitative test for simultaneous detection and identification of multiple nucleic acids of viruses and bacteria in nasopharyngeal aspirate. A respiratory tract sample of at least $0.3-\mathrm{mL}$ volume $(300 \mu \mathrm{L})$ was taken from each patient. The test simultaneously identifies the following viruses and bacteria: adenovirus, coronavirus 229E, coronavirus HKU1, coronavirus NL63, coronavirus OC43, influenza A (with subtyping for hemagglutinin $\mathrm{H} 1, \mathrm{H} 1-2009$ and $\mathrm{H} 3$ genes) and 
influenza B virus, human metapneumovirus, parainfluenza 1, parainfluenza 2, parainfluenza 3 and parainfluenza 4 virus, respiratory syncytial virus, rhinovirus/ enterovirus, Bordetella pertussis, Chlamydophila pneumoniae and Mycoplasma pneumoniae.

The sample was introduced into the FilmArray RP cartridge, the cartridge was placed in the FilmArray instrument/Module and the test was started; a test report was automatically generated at the conclusion of the analysis. The entire process takes about one hour. The test has a sensitivity and specificity of $95 \%$ and $99 \%$, respectively. ${ }^{13}$

For each positive case, the following was analyzed: clinical-radiological diagnosis established by the treating physician, prescribed treatment, behavior regarding the treatment that was followed when the test result was obtained, antimicrobial prescription time and patient conditions at discharge.

\section{Results}

The initial sample consisted of 172 patients of all ages, out of which 38 were excluded for not having a complete medical record.

Final sample included 134 patients; $49.2 \%$ were males and $50.8 \%$ were females; patients of all ages were included and $56 \%$ were infants, $16 \%$ preschool children, $2 \%$ schoolchildren, $4 \%$ adolescents and $22 \%$ adults.

Among the results of the viral panel, RSV was identified in $25 \%$ of samples, followed by influenza A (18\%), rhinovirus/enterovirus (10\%), metapneumovirus $(10 \%)$, influenza B (9\%), parainfluenza (5\%), coronavirus (4\%), B. pertussis (2\%), M. pneumoniae $(1 \%)$, and more than one virus was isolated in $16 \%$ of samples (Fig 1).

Radiological-clinical diagnoses for the entire patient sample were: pneumonia in $42 \%, 10 \%$ had bronchiolitis, $17 \%$ had influenza, $8 \%$ had bronchitis, asthma attack was identified in $2 \%$, rhinopharyngitis in $2 \%$ and $19 \%$ had other diagnoses.

Out of $100 \%$ of patients, $58 \%$ received only antibiotic treatment upon admission, $13 \%$ received combined treatment (antibiotic + antiviral), $27 \%$ of patients received symptomatic treatment, and $2 \%$ were treated with antivirals from the beginning.

Upon obtaining a positive viral panel result, of the patients who initially received antibiotics $(71 \%)$, only in $10 \%$ was this treatment discontinued; $2.3 \%$ continued only with the antiviral that was administered since admission; in $1.5 \%$, antibiotic was discontinued and antiviral was added; and in $6.2 \%$, antibiotic was discontinued and symptomatic treatment was received; $22 \%$ had antiviral added to the antibiotic treatment they were already receiving, and $8 \%$ continued with combined treatment; $31 \%$ continued with antibiotic only; $12 \%$ of the patients continued only with symptomatic treatment, $7 \%$ had an antibiotic added to their symptomatic treatment after a respiratory panel positive result, and $10 \%$ had antiviral added to symptomatic treatment.

After a positive result, $38 \%$ received antibiotics as definitive treatment, $30 \%$ were treated with combined treatment (antibiotic + antiviral), $13.8 \%$ were treated with antiviral alone and $18.2 \%$ with symptomatic treatment (Fig. 2).

Out of $68 \%$ of patients who received antibiotics empirically or as definitive treatment, $41 \%$ received more than one antibiotic during hospital stay. As monotherapy or associated with another antibiotic, $45 \%$ received a cephalosporin; $17 \%$, macrolides; $11 \%$, quinolones; and $5 \%$, other agents. In $39 \%$ of the patients, diagnoses or laboratory test results (such as bronchial secretion culture) were found to justify the use of antibiotics.

Days of hospital stay in patients who received antibiotic treatment despite a positive viral panel being obtained $(38 \%)$ were reported to range between 5 and 6 days, as it was also observed in $30 \%$ who were treated with antibiotics and antivirals. In $13.8 \%$ who received antiviral treatment, hospital stay ranged from 3 to 4 days, while in those who received symptomatic treatment, hospital stay ranged from 4 to 5 days. There were two deaths (1.5\%), one patient had to be transferred to a high specialty unit and 131 had no complications and were discharged due to improvement of their condition.

\section{Discussion}

There are various studies that show a high prevalence of viral agents in both adult and pediatric patients as the cause of acute respiratory processes that lead to hospitalization. ${ }^{14,15}$

Knowing the etiology and clinical presentation of respiratory diseases, supported by current methods for diagnosis, should facilitate decision-making on the appropriate treatment for each patient. When clinical presentation maintains an adequate correlation with laboratory findings, physicians have the elements to support their therapeutic decision. ${ }^{5}$ 


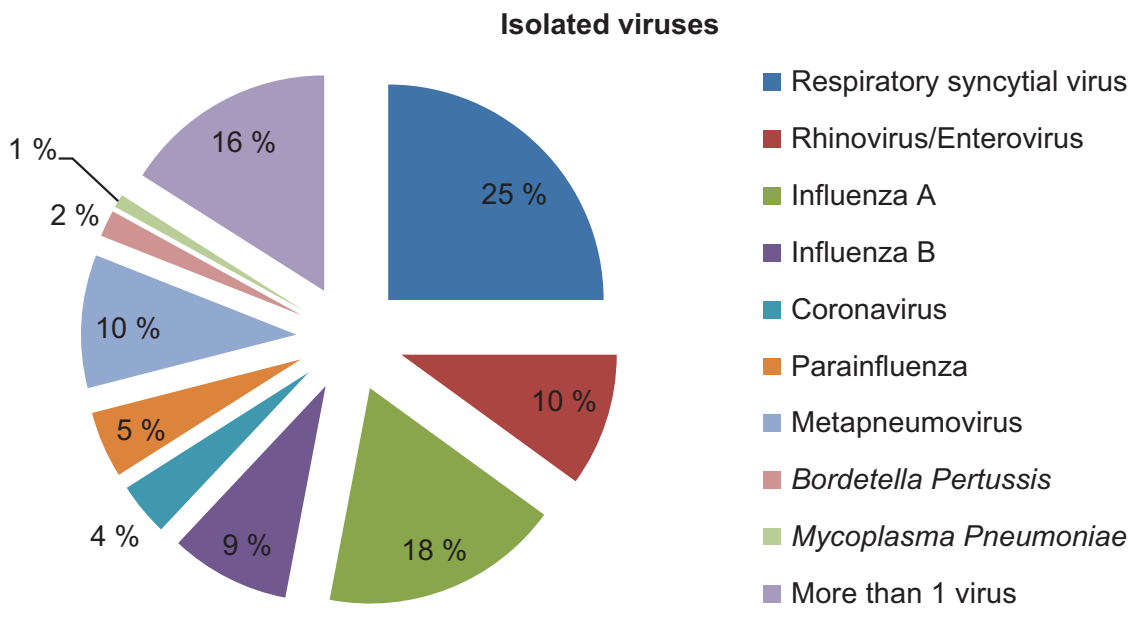

Figure 1. Percentage distribution of viruses identified by polymerase chain reaction in nasopharyngeal samples.

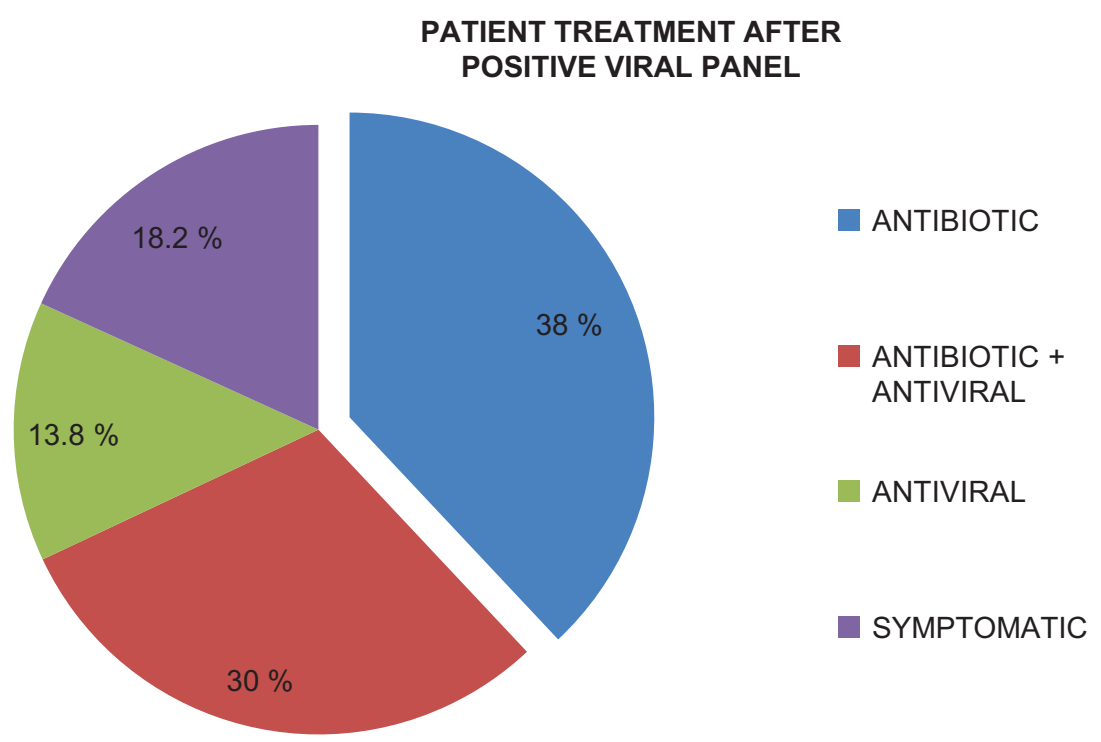

Figure 2. Final treatment received by patients despite having a positive viral report.

In this study, we evaluated how much a respiratory panel PCR positive result influences on the treatment received by patients.

Worldwide, the behavior of reducing the use of antibiotics when a viral panel positive result is obtained is variable. In a study in Sweden, of the patients in whom a virus was identified, $21 \%$ were definitively treated with antibiotics. ${ }^{9}$ In the present study, $71 \%$ of the patients received an antibiotic upon admission, and $68 \%$ received it as definitive treatment even when a positive result for virus was subsequently obtained. The result is similar to the experience in Sri Lanka, ${ }^{16}$ in outpatients, where testing for detection of viruses during the influenza endemic period could reduce antibiotic use only by $20 \%$, from 83.7 to $62.3 \%$, despite a positive test for influenza; the high volume of patients and fear of bacterial superinfection were important factors for excessive antibiotic use in that study.

The design in our study does not allow the factors that influenced treating physicians to continue prescribing antibiotics to be known; in $39 \%$ of medical records, some justification was found for their use due to bacterial superinfection, no data consistent with greater severity were found, and perhaps the most influential factor was patient hospitalization. The 
antibiotics that were most commonly used as definitive treatment were cephalosporins (45\%) and macrolides (17\%).

In the analyzed samples, there was a predominance of RSV in $25 \%$, followed by influenza A with $18 \%$ and $B$ with $9 \%$; in $16 \%$ of the samples, more than one virus was detected. In a study carried out in our country in patients with influenza-like illness, the proportion of identified viruses was predominantly comprised of rhinovirus (36.5\%), followed by influenza virus (22.6\%), coronavirus (17.9\%) and RSV (14.2\%), although the samples appear to correspond to influenza seasons; of this sample, $47 \%$ of subjects were hospitalized. ${ }^{17}$ This reflects the wide circulation of respiratory viruses, which can determine moderate to severe conditions that require hospital management. In particular, RSV and influenza virus tend to cause more severe conditions. In winter season, rhinoviruses predominate; however, in cases with community-acquired pneumonia or with respiratory infection that requires hospitalization, influenza virus, RSV and metapneumovirus predominate. ${ }^{17,18}$ There is discrepancy on whether the presence of viral coinfections can cause a more severe course of infection. ${ }^{17,18}$

Despite the fact that antimicrobial resistance is currently one of the main public health problems in the world, ${ }^{11}$ irrational antibiotic prescription continues. Assigning a correct weight to the association of laboratory tests that detect viruses in patients with moderate to severe respiratory infections is necessary, as well as recognizing that, in most these cases, the use of antimicrobials is not required. There are studies that clearly find respiratory viruses in patients with community-acquired pneumonia and patients with severe respiratory infections that require management in intensive care units ${ }^{18,19}$ in whom no bacterial association was demonstrated. Medical behavior regarding therapeutic decision in a private hospital shows that despite having carried out an investigation searching for viruses as the cause of acute respiratory infection, the obtained results were not used to generate a modification regarding the use of antibiotics.

Knowing which are the reasons that make for antimicrobial management to be continued even in the presence of viral etiology will be necessary. Probably there is no trust in laboratory tests because their sensitivity and specificity are unknown, or there is fear of not offering a treatment "that can cure the infection", especially because there are few antiviral alternatives, and greater family pressure, since, in private hospitals, treating physicians assume the decisions and responsibilities with their patients.

Greater dissemination of information on viral participation in respiratory infections of moderate to severe evolution that do not require antimicrobial treatment is required. Probably, it will take some time to accept the usefulness of the new diagnostic laboratory techniques that have recently been incorporated into hospitals.

\section{Conflict of interests}

The authors declare that they have no conflicts of interest.

\section{Funding}

The authors did not receive any sponsoring to carry out this article.

\section{Ethical disclosures}

Protection of human and animal subjects. The authors declare that no experiments were performed on humans or animals for this research.

Confidentiality of data. The authors declare that they have followed the protocols of their work center on the publication of patient data.

Right to privacy and informed consent. The authors declare that no patient data appear in this article.

\section{References}

1. Lopardo G, Calmaggi A. Consenso sobre diagnóstico y tratamiento de infecciones de vías respiratorias altas. Medicina. 2012;72:484-94.

2. Eiros JM, Ortiz de LR. Diagnóstico microbiológico de las infecciones virales respiratorias. Enferm Infecc Microbiol Clin. 2009;27(3):168-77.

3. Diagnóstico y manejo de la infección aguda de vías aéreas superiores en pacientes mayores de 3 meses hasta 18 años de edad [Internet]. Gobierno de Mexico, Catálogo maestro, Guías de práctica clínica; September 4, 2015 [updated: November 2016]. Available at: https://cenetec-difusion.com/gpc-sns/?p=1078

4. Información relevante: infecciones respiratorias agudas [Internet]. Mexico: Subsecretaría de Prevención y Promoción de la Salud, Dirección General de Epidemiología (DGE), Sistema de Notificación Semanal de casos Nuevos [accessed: March 23, 2017]. Available at: https://www.gob. $\mathrm{mx} / \mathrm{cms} /$ uploads/attachment/file/220600/IRA_2017_SE16.pdf

5. Guía de vigilancia epidemiológica y recomendaciones para la prevención y diagnóstico de las infecciones respiratorias agudas en Argentina [Internet]. Argentina: Ministerio de Salud; 2018 updating. Available at: http:// www.entrerios.gov.ar/msalud/wp-content/uploads/2018/06/2018-07_ guia-infecciones-respiratorias-agudas.pdf

6. Pneumonia [Internet]. American Lung Association; 2020. Available at: http://www.lung.org/lung-health-and-diseases/lung-disease-lookup/pneumonia

7. Foro de las Sociedades Respiratorias Internacionales. El impacto global de la Enfermedad Respiratoria. Second edition. Mexico: Asociación Latinoamericana de Tórax; 2017.

8. Bayona Y, Niederbacher J. Infecciones respiratorias virales en pediatría: generalidades sobre fisiopatogenia, diagnóstico y algunos desenlaces clínicos. Med UIS. 2015;28(1):133-41. 
9. Rhedin S, Lindstrand A. Clinical utility of PCR for common viruses in acute respiratory illness. Pediatrics. 2014;133(3):538-45.

10. Infectious Diseases Society of America (IDSA). Antimicrobial resistance: a public health crisis. 2016. http://www.idsociety.org/topic_antimicrobial_resistance/\#

11. Resistencia a los antimicrobianos [Internet]. Organización Mundial de la Salud; October 13, 2020. Available at: https://www.who.int/antimicrobial-resistance/es/

12. Hersh AL, Jackson MA. Principles of judicious antibiotic prescribing for upper respiratory tract infections in pediatrics. Pediatrics. 2013;132(6):1146-54.

13. BioFire Diagnostics. FilmArray Respiratory Panel (PR). Instructions manual 2016. pp. 7-31.

14. Yoshii Y, Shimizu K, Morozumi M, Chiba N, Ubukata K, Uruga H, et al. Detection of pathogens by real-time PCR in adult patients with acute exacerbation of bronchial asthma. BMC Pulm Med. 2017:17:150.

15. Jiang W, Wu M, Zhou J, Wang Y, Hao C, Ji W, et al. Etiologic spectrum and occurrence of coinfections in children hospitalized with community-acquired pneumonia. BMC Infect Dis. 2017;17:787.
16. Tillekeratne LG, Bodinayake CK, Nagahawatte A, Vidanagama D, Devasiri V, Arachchi WK, et al. Use of rapid influenza testing to reduce antibiotic prescriptions among outpatients with Influenza-Like illness in Southern Sri Lanka. Am J Trop Med Hyg. 2015; 93(5):1031-7.

17. Noyola DE, Hunsberger S, Valdés Salgado R, Powers JH $3^{\text {rd }}$, Galindo-Fraga A, Ortiz-Hernández AA, et al. Comparison of rates of hospitalization between single and dual virus detection in a Mexican cohort of children and adults with Influenza-Like illness. Open Forum Infect Dis. 2019;6(11):ofz424.

18. Rhedin S, Lindstrand A, Hjelmgren A, Ryd-Rinder M, Öhrmalm L, Tolfvenstam $\mathrm{T}$, et al. Respiratory viruses associated with community-acquired pneumonia in children: matched case-control study. Thorax. 2015;70(9):847553.

19. Becerra M, Fiestas V, Tantaleán J, Mallma G, Alvarado M, Gutiérrez V, et al. Etiología viral de las infecciones respiratorias agudas graves en una unidad de cuidados intensivos pediátricos. Rev Peru Med Exp Salud Publica. 2019;36(2):23108. 